Abstracta Iranica Abstracta Iranica

Revue bibliographique pour le domaine irano-aryen

Volume 29 | 2008

Comptes rendus des publications de 2006

\title{
Democracy in Iran: history and the quest for liberty. Oxford University Press, 2006, 232 p.
}

\section{Anicée Van Engeland}

\section{(2) OpenEdition}

1 Journals

Édition électronique

URL : http://journals.openedition.org/abstractairanica/32312

DOI : 10.4000/abstractairanica.32312

ISSN : 1961-960X

\section{Éditeur :}

CNRS (UMR 7528 Mondes iraniens et indiens), Éditions de l'IFRI

\section{Édition imprimée}

Date de publication : 15 mai 2008

ISSN : 0240-8910

\section{Référence électronique}

Anicée Van Engeland, «Democracy in Iran: history and the quest for liberty. Oxford University Press, 2006, 232 p. », Abstracta Iranica [En ligne], Volume 29 | 2008, document 366, mis en ligne le 15 septembre 2008, consulté le 26 septembre 2020. URL : http://journals.openedition.org/ abstractairanica/32312 ; DOI : https://doi.org/10.4000/abstractairanica.32312

Ce document a été généré automatiquement le 26 septembre 2020.

Tous droits réservés 


\title{
Democracy in Iran: history and the quest for liberty. Oxford University Press, 2006, $232 \mathrm{p}$.
}

\author{
Anicée Van Engeland
}

1 Les AA. considèrent que l'Iran est un pays difficilement pénétrable à plusieurs niveaux. L'élection du Président Ahmadinejad ne fait que compliquer les différentes approches américaines du cas iranien. Ils analysent ce nouveau président sous tous les angles et estiment qu'il est la preuve du rejet populaire de la branche conservatrice du pays. Ils constatent aussi que les réformistes semblent dépassés par la situation. La conclusion de l'ouvrage est qu'en dépit de cette situation politique compliquée, il y a une place pour la démocratie en Iran.

\section{INDEX}

Thèmes : 13.1. Iran

\section{AUTEURS}

ANICÉE VAN ENGELAND

European University Institute - Florence 